NURSING TASKS IN THE MATERIAL STORAGE CENTER OF HOSPITAL INSTITUTIONS ${ }^{1}$

\author{
Rosineide Feres Gil², Silvia Helena Camelo³, Ana Maria Laus
}

\footnotetext{
${ }^{1}$ Paper taken from the thesis - Nursing activities at the Material Storage Center of Hospital Institutions, presented to the University of São Paulo (USP) at Ribeirão Preto College of Nursing (EERP), 2012.

${ }^{2}$ M.Sc. in Nursing. Nurse, Material Storage Center, Hospital Universitário de Londrina. Paraná, Brazil. E-mail: rfg.gil@gmail.com

${ }^{3}$ Ph.D. in Nursing. Faculty, General and Specialized Nursing Department, EERP/USP. São Paulo, Brazil. E-mail: shcamelo@ eerp.usp.br

${ }^{4}$ Ph.D. in Nursing. Faculty, General and Specialized Nursing Department, EERP/USP. São Paulo, Brazil. E-mail: analaus@ eerp.usp.br
}

\begin{abstract}
This cross-sectional descriptive study aims to identify the activities of nurses at Material Storage Centers of hospital institutions according to the activity profile and frequency of application. Subjects were selected through the reference chain or "snowball" technique. Data were collected using Google Docs offline ${ }^{\circledR}$, posting a questionnaire on professional specification and specific activities of the nurses at Material Storage Centers. As to the respondents' profile, the results show the age group 21 to 30 years, nurses with specialization in Material Storage Centers (33.4\%). As to the 25 activities under investigation, 15 activities present a daily frequency, nine activities a monthly frequency and 14 activities appear as never performed. This shows the need to incorporate new questions on the future of the work in Material Storage Centers, suggesting further research in the area.
\end{abstract}

DESCRIPTORS: Nursing staff. Professional nursing role. Sterilization. Hospital materials administration.

\title{
ATIVIDADES DO ENFERMEIRO DE CENTRO DE MATERIAL E ESTERILIZAÇÃO EM INSTITUIÇÕES HOSPITALARES
}

RESUMO: Estudo descritivo e transversal que objetiva identificar as atividades dos enfermeiros de Centro de Material e Esterilização de instituições hospitalares, segundo o perfil de atividades e frequência de realização. A seleção dos sujeitos realizou-se pela técnica em cadeia de referência ou "bola de neve". Os dados foram coletados com a ferramenta Google Docs Offline®, com questionário autoaplicado contendo a caracterização profissional e as atividades específicas dos enfermeiros de Centro de Material e Esterilização. Os resultados evidenciam, em relação ao perfil dos respondentes, faixa etária entre 21 e 30 anos e com especialização na área de Centro de Material e Esterilização (33,4\%). Das 25 atividades relacionadas, 15 atividades apresentam frequência de realização diária, nove atividades, realização mensal e 14 atividades aparecem como nunca sendo realizadas. Evidencia-se a necessidade de incorporar novas questões sobre o futuro do trabalho no Centro de Material e Esterilização, sugerindo o desenvolvimento de novas pesquisas na área.

DESCRITORES: Recursos humanos de enfermagem. Papel do profissional de enfermagem. Esterilização. Administração de materiais no hospital.

\section{ACTIVIDADES DEL ENFERMERO EN UN CENTRO DE MATERIAL $Y$ ESTERILIZACIÓN EN INSTITUCIONES HOSPITALARIAS}

\footnotetext{
RESUMEN: Este estudio descriptivo y transversal objetiva identificar las actividades de los enfermeros del Centro de Material y Esterilización de instituciones hospitalarias según el perfil de las actividades y la frecuencia de realización. La selección de los sujetos se realizó por la técnica en cadena de referencia o el llamado en portugués "bola de neve" (pelota de nieve). Los datos fueron colectados con la herramienta Google Docs Offline ${ }^{\circledR}$, con cuestionarios auto aplicado conteniendo caracterización profesional y las actividades especificas de los enfermeros y el Centro de Material y Esterilización. Los resultados evidencian, en relación al perfil de los encuestados, faja etaria entre 21 y 30 años, enfermeros con especialización en el área de Centro de Material y Esterilización (33,4\%). De las 25 actividades relacionadas, 15 actividades presentan frecuencia de realización diaria, nueve actividades con realización mensual y 14 actividades aparecen como nunca siendo realizadas. Se evidencia la necesidad de incorporar nuevas cuestiones sobre el futuro del trabajo en la Centro de Material y Esterilización, sugiriéndose entonces el desarrollo de nuevas pesquisas en el área.

DESCRIPTORES: Recursos humanos de enfermería. Papel del profesional de enfermería. Esterilización. Administración de materiales en el hospital.
} 


\section{INTRODUCTION}

The Material Storage Center (MSC) stands out in the context of health organizations in a rather peculiar way, as it supports all care and diagnostic services that need dental-medicalhospital products for care delivery to their users. ${ }^{1}$

One of the factors that decisively contributed to the implementation and consolidation of MSCs in hospitals was health teams' awareness about the need to control hospital infections, which directly affect the quality of care delivery and often entail extended hospitalizations and, hence, increased hospital care costs. Understanding about the influence of material cleansing, disinfection and sterilization procedures on hospital infection prevention and control underline the importance and responsibility of the MSC in the context of health institutions, as the existence of errors in these processes exert a determinant influence on the emergence of complications in patients. ${ }^{2-3}$

The MSC comes with a distinguished work process and specific activity area for nurses who, using a range of scientific and technological knowledge to coordinate the work, seek integration with consumer units and support units at the hospital institution, characterizing a relation of interdependence.

Nurses' work at the MSC should be considered as legitimate care, considering that it equips direct care delivery, acknowledging that material preparation is essential in daily nursing care. ${ }^{4-5}$

Concerning the functions at this unit, the competences required from nurses are related to the management of the sector, technical-care activities and human capital management, demanding a set of structured knowledge that permits the achievement of their proposed work goals at a unit with such great accountability.

In that perspective, another challenge MSC nurses are confronted with is related to the work process itself at the unit, strongly marked by invisible action, considering that indirect care is less value, although this practice is based on tacit and scientific knowledge that could enhance social acknowledgement. ${ }^{6}$

The characteristics of MSC work are very distinct from other hospital units. Despite legal regulations on adequate MSC structures, in practice, it had been verified that they do not correspond to the current panorama, in which the functional requisites are not attended to, in terms of neither physical structure nor activities performed. As a result of that panorama, a range of services is available, which consequently affect the set of activities the professionals working at the unit perform.

In the literature, various documents have been published, offering legal solutions that indicate not only the MSCs' functional scope, but also the activities the nursing team is supposed to develop. This description is based on the finding that, traditionally, nursing is in charge of management at this unit, given its accountability for the organization of the therapeutic space in he hospital.

Hence, concerning the execution of the MSC nursing professionals' activities, the Federal Nursing Council (COFEn) defined and determines, in its Decree 94406/1987, which regulates Law $7.498 / 86$, that the task of auxiliary nurses includes cleaning activities, putting material and equipment in order, as well as disinfection and sterilization, under nursing supervision and orientation. ${ }^{7}$

Then, Collegiate Board Resolution 307/2002 was published, which endorses the aspects inherent in the establishment of this unit's own activities, ${ }^{8}$ without addressing various technical-administrative activities though, such as planning, organization, coordination, orientation, supervision, training and continuing education, activities and responsibilities that are part of nurses' daily work in MSC. ${ }^{9}$

In the same sense, with a view to strengthening the legal standards elaborated to support nurses working at MSCs, in 2007, the Brazilian Society of Surgical, Anesthetic Recovery and Material Storage Center Nurses (SOBECC) published an extensive list of activities established for the nursing team at that unit. ${ }^{10}$

Considering the complexity of the work process at that unit and of events involving the quality of processes related to the reprocessing of different medical-hospital material, recently, RDC 15.2012 was published to set the best practices for the functioning of health product processing services and, among these, the responsibilities of the nursing team are described. ${ }^{11}$

In view of that document, COFEn publishes Resolution 424/2012, in view of the need to regulate the responsibilities of nursing team members working at Material Storage Centers in Brazil. That resolution has been considered a guideline for professional nursing practice at that unit. ${ }^{12}$

Among the publications that establish and recommend a task profile, a study should be mentioned that was developed at hospitals in São Paulo City, which are considered referral institu- 
tions and performance benchmarks for the work processes accomplished there, in which the nursing team activities at MSCs were identified and validated. That research permitted the elaboration of a flowchart representing the actions undertaken at the unit, including six areas, 25 work subgroups and 110 activities, besides 25 nursing activities. ${ }^{3}$

Given the particularity of the institutions where this research was undertaken, the investigation of different hospital realities in Brazil was considered relevant, especially concerning the work of MSC nurses, with a view to gaining a more comprehensive view of work at these units and understanding the complexity and peculiarity of this professional's activities, as well as to reassert their importance in the management of that service.

In view of these considerations and the relevance of the theme for professional nursing practice, this research was undertaken to identify nurses' activities in MSCs of hospital institutions according to the activity profile and the frequency of their accomplishment.

\section{METHOD}

A descriptive and cross-sectional study was undertaken. The population consists of clinical nurses and/or nurse faculty in Material Storage Centers of public, private or non-profit hospitals in Brazil, who possess professional experience and expertise in the research area. To select the subjects, the snowball technique was chosen, ${ }^{13}$ considering the importance of experience or expertise on the subject to achieve a consensus on specialized ideas.

The recruitment started with the signaling of an initial key informant, who was the Coordinator of the Perioperative Nursing Area at the University of São Paulo at Ribeirão Preto College of Nursing, an acknowledged academic institution in Brazil and internationally. That person was asked to indicate the name, function and e-mail address of three professionals who might comply with the sample composition criteria.

After identifying the probable participants, the research was presented by e-mail, through a document that presented the project to the identified professionals and invited them to participate. An exclusive e-mail address was created for this purpose. If they agreed to participate, the Informed Consent Term was sent, followed by the questionnaires.
For data collection, two self-applied instruments were elaborated, one to characterize the participants, and the other called "Questionnaire about specific nursing activities at the MSC", including 25 specific nursing tasks at this service, constructed based on the study developed in a Master's thesis. ${ }^{3}$ The participants were expected to assess and score the frequency of the activity described on a Likert scale, ranging from never to rarely, daily, weekly and monthly. One alternative should be marked for each instrument question, and completion was essential to move on to subsequent pages and access the complete questionnaire. Besides the list of activities, space was provided to add any activities not addressed in the list, according to the respondent's opinion.

To collect the research information, advice was sought from an informatics expert, who indicated the tool Google Docs Off line®, which was considered highly versatile and permits different uses, including a simple questionnaire, registration form, opinion poll, survey, etc. In addition, it can easily be shared by e-mail or through a direct link, making this tool a very interesting option for teachers, students, researchers and professionals whose work involves the application of questionnaires. ${ }^{14}$ The collected answers are automatically included in a worksheet, making it easy to produce statistics.

The entire document flow in this research was done by e-mail, and the researcher had exclusive access to the results. A 15-day deadline was set for the participants to return the questionnaires and data were collected between July 2011 and April 2012.

For the sake of data analysis, descriptive statistics were applied to the study variables, using frequency distribution, and the results were grouped in tables.

In compliance with National Health Council Resolution 196/96, approval for the project was obtained from the Research Ethics Commission at the University of São Paulo at Ribeirão Preto College of Nursing (Protocol 1331/2011).

\section{RESULTS AND DISCUSSION}

Eighty-two professionals were contacted and agreed to participate. They received the link to the data collection instrument by e-mail and 31 professionals responded, who constituted the research sample.

The choice of the electronic tool was based on a literature review, in which studies were identified that indicate the use of technological tools for 
studies that use the web as an ally in the research process. When well used, these auxiliary and support resources make it easier for the investigator to accomplish the research. ${ }^{15}$

Online research can meet with greater resistance to answer the study, as many users are fearful that their data might be used improperly or for criminal purposes, and therefore prefer avoiding access to unknown websites that may weaken their personal security. ${ }^{16}$

Our study supports the assertion that, despite the enhanced development of communication methods and technologies that permit faster and more precise contact with the population of interest for the research, resistance was faced to participate in the online research.

As regards the participating nurses' characteristics, table 1 displays the variables collected.

Table 1 - Characterization of nurse participants considering age range, gender and graduation time, activity area and specialization. Brazil, 2012

\begin{tabular}{lrr}
\hline Variables & $\mathrm{n}$ & \multicolumn{1}{c}{$\%$} \\
\hline Age range & 11 & 35.49 \\
$21 \mid-30$ & 8 & 25.80 \\
$31 \mid-40$ & 7 & 22.58 \\
$41 \mid-50$ & 5 & 16.13 \\
$51 \mid-60$ & & \\
Gender & 29 & 93.55 \\
Female & 2 & 6.45 \\
Male & & \\
Graduation time (years) & 11 & 35.49 \\
$01 \mid-05$ & 6 & 19.35 \\
$06 \mid-10$ & 2 & 6.45 \\
$11 \mid-15$ & 4 & 12.90 \\
$16 \mid-20$ & 3 & 9.68 \\
$21 \mid-25$ & 5 & 16.13 \\
$26 \mid-30$ & & \\
Activity area & 3 & 9.68 \\
Teaching & 28 & 90.32 \\
Care & & \\
Activity at MSC (in years) & 18 & 58.08 \\
$01-05$ & 4 & 12.90 \\
$06-10$ & 5 & 16.13 \\
$11-15$ & 2 & 6.45 \\
$16-20$ & 1 & 3.22 \\
$21-25$ & 1 & 3.22 \\
$26-30$ & & \\
Specialization & 25 & 80.65 \\
Yes & 6 & 19.35 \\
No & & \\
\hline & &
\end{tabular}

The data demonstrate that, among the nurse experts in MSC, $93.55 \%$ are female, between 21 and 60 years of age, with $35.49 \%$ between 21 and 30 years old. As regards the graduation time, $61.29 \%$ graduated less than 15 years early, but mostly between one and five years. Concerning professional experience in the area, $58.08 \%$ have between one and five years of experience in the sector.

Brazilian literature reveals few studies that describe the profile of nurses working at MSC services. In a study of 18 health institutions in Curitiba-PR, aimed at describing nurses' perception about the elements of their work process at the MSC, $93.3 \%$ of the subjects were female, between 41 and 50 years of age (53.3\%), up to five years since graduation (53.8\%) and between two and five years of experience at MSC (60\%). ${ }^{17}$ Except for the age range, graduation and experience characteristics are similar, showing the profile of professionals working at this specialized service.

The data regarding complementary education indicate that $33.35 \%$ of the participants hold a specific specialization degree in MSC. Studies have shown that professional education should contribute to the renewal of the administrative dynamics of nursing services, valuing the specific knowledge of MSC nurses and the importance of this sector for the quality of care delivery. ${ }^{18}$

As regards the professionals' activities, focused on in this research, the data are described in table 2, together with the respective frequency of their accomplishment.

The analysis of the answers indicates that most of the respondents marked 15 of the activities listed as daily and nine as monthly. Among the activities indicated as daily and accomplished most frequently, the following stand out in decreasing order: supervision of activities at the unit; confirmation of surgery program, checking availability of sterile materials and garment; attendance to consumer units; coordination of work process at the unit; team monitoring in execution of activities, mainly new professionals; supervision of functioning of equipment used in each work area; confirmation of surgery program, checking delivery of consigned materials; and verification of sterilization control documents. 
Table 2 - Accomplishment frequency of specific activities for Material Storage Center nurses according to research participants. Brazil, 2012

\begin{tabular}{|c|c|c|c|c|c|}
\hline Activities & $\begin{array}{c}\text { Daily } \\
(\%)\end{array}$ & $\begin{array}{c}\text { Week } \\
(\%)\end{array}$ & $\begin{array}{c}\text { Month } \\
(\%)\end{array}$ & $\begin{array}{c}\text { Rare } \\
(\%)\end{array}$ & $\begin{array}{c}\text { Never } \\
(\%)\end{array}$ \\
\hline 1) Coordination of work process at the unit. & 87.10 & 9.68 & - & - & 3.22 \\
\hline 2) Supervision of activities at the unit. & 96.78 & 3.22 & - & - & - \\
\hline $\begin{array}{l}\text { 3) Definition of work scale in each activity area of the } \\
\text { nursing team. }\end{array}$ & 45.16 & 12.90 & 41.94 & - & - \\
\hline $\begin{array}{l}\text { 4)Team monitoring in execution of activities, mainly fo- } \\
\text { cused on new professionals. }\end{array}$ & 80.65 & 16.13 & 3.22 & - & - \\
\hline $\begin{array}{l}\text { 5) Supervision of equipment functioning used in each } \\
\text { work area. }\end{array}$ & 80.65 & 16.13 & 3.22 & - & - \\
\hline 6) Monitoring of product, input and equipment tests. & 41.94 & 25.80 & 32.26 & - & - \\
\hline $\begin{array}{l}\text { 7) Supervision and control of consigned material recep- } \\
\text { tion. }\end{array}$ & 67.75 & 16.13 & - & 3.22 & 12.90 \\
\hline $\begin{array}{l}\text { 8) Supervision and control of use and charges for con- } \\
\text { signed material. }\end{array}$ & 48.39 & 16.13 & - & - & 35.48 \\
\hline 9) Supervision and control of return of consigned material. & 54.84 & 22.58 & - & 6.45 & 16.13 \\
\hline $\begin{array}{l}\text { 10) Confirmation of daily surgery program, checking } \\
\text { delivery of consigned materials. }\end{array}$ & 80.65 & - & - & 3.22 & 16.13 \\
\hline $\begin{array}{l}\text { 11) Confirmation of surgery program, checking availabil- } \\
\text { ity of sterile materials and garment. }\end{array}$ & 93.56 & - & - & 3.22 & 3.22 \\
\hline 12) Verification of sterilization control documents. & 77.42 & 16.14 & 3.22 & 3.22 & - \\
\hline $\begin{array}{l}\text { 13) Monitoring and control of sterile material and garment } \\
\text { inventories. }\end{array}$ & 70.97 & 22.58 & - & 6.45 & - \\
\hline $\begin{array}{l}\text { 14) Monitoring and evaluation of material and equipment } \\
\text { maintenance. }\end{array}$ & 51.62 & 25.80 & 22.58 & - & \\
\hline $\begin{array}{l}\text { 15) Monitoring and evaluation of equipment validation } \\
\text { and qualification. }\end{array}$ & 25.80 & 22.58 & 29.04 & 19.36 & 3.22 \\
\hline 16) Monitoring, planning and execution of training. & 3.22 & 12.90 & 61.30 & 22.58 & - \\
\hline $\begin{array}{l}\text { 17) Participation in material, equipment and input pur- } \\
\text { chasing. }\end{array}$ & 16.13 & 9.68 & 38.70 & 29.04 & 6.45 \\
\hline 18) Participation in employee performance assessment. & 22.58 & 3.22 & 58.07 & 16.13 & - \\
\hline $\begin{array}{l}\text { 19) Participation in administrative and management meet- } \\
\text { ings involving the MSC. }\end{array}$ & 3.22 & 22.58 & 48.39 & 19.36 & 6.45 \\
\hline $\begin{array}{l}\text { 20) Participation in programs, commissions, courses and } \\
\text { events involving the MSC. }\end{array}$ & 3.22 & 12.90 & 51.62 & 29.04 & 3.22 \\
\hline $\begin{array}{l}\text { 21) Participation in definition of occupational risk preven- } \\
\text { tion and occupational safety programs. }\end{array}$ & 3.22 & - & 38.70 & 35.50 & 22.58 \\
\hline 22) Research development. & - & - & 9.67 & 48.39 & 41.94 \\
\hline 23) Unit productivity control. & 22.58 & 3.22 & 61.30 & 3.22 & 9.68 \\
\hline 24) Attendance to consumer units. & 90.33 & 6.45 & - & 3.22 & \\
\hline 25) Monitoring of quality indicator assessment at the unit. & 19.36 & 9.67 & 41.94 & 6.45 & 22.58 \\
\hline
\end{tabular}

Management is the main nursing activity at the MSC, comprising different functions, such as planning, elaboration of administrative and operational instruments, material and human resource management and supervision. Nurses' activities are concentrated on material and staff organization, with processed or reprocessed medical-hospital products as their work object. ${ }^{19}$ The instruments of these professionals' work process are knowledge, communication and interpersonal relations and planning.

These data are similar to a study of ten MSC nurses in Campinas-SP, which showed management as the main activity of nurses at this unit, including different functions, such as planning, elaboration of administrative and operations instruments, material and human resource management and supervision. In this study, the man- 
agement activities all participating nurses most indicated were material resource management, mainly prediction and provision, control and verification of preparation. ${ }^{20}$

In the hospital area, material resource management has stood out, mainly as a result of technological advances in recent decades. The incorporation of sophisticated technology is illustrated by the increased complexity of care practices and the challenges public and private managers face in view of the enhanced supply of products, and permits the monitoring of product quality, guaranteeing safety for patients and health teams. ${ }^{21}$

The Material Storage Center is a service that articulates with practically all hospital sectors, as it provides medical products to so-called consumer units, including not only the Surgical Center, but also hospitalization units, the outpatient clinic, the emergency unit, among others. ${ }^{22}$

The nursing staff has detailed knowledge about care and service dynamics, and is generally responsible for managing materials and health services at the sector. This clearly shows the relevance of material resource management for nursing work. ${ }^{23}$

Initially, the MSC was responsible for processing, storing and distributing dentalmedical-hospital products and equipment, using different work instruments (equipment, material, techniques, standards, communication, scientific knowledge, in-service education, management, etc.). Nowadays, however, the service goes beyond and is aimed at delivering indirect care through the availability of safe products that support direct care delivery by other sectors (consumer units) in response to the clients' health needs. ${ }^{4}$

MSC nurses need to demonstrate their competences with regard to the modernization of the production process, and mainly the valuation and constant recycling of human resources, through effective continuing education that is committed to the development of nursing professionals' full range of potential, in response to the new technologies that are put in practice. ${ }^{18}$

One aspect that demands careful analysis refers to activities related to the nurses' supervision of the functioning of equipment used in each work area. For this purpose, they need to know their equipment and their proper functioning, so as to guarantee the reliability and safety of client care. Monitoring the equipment and training the employees responsible for operating the machines is fundamental for the service to perform well.

Concerning medical-hospital material, MSC nurses' responsibility to verify the surgical program of the consigned material during its reception, usage control, charge and return of this material represents a daily task, but not for all respondents. At some institutions, this responsibility does not exist for these professionals, indicating a different structure of the MSC work process, predominantly with regard to surgical material.

Another surprising aspect relates to the nurses' lack of participation in research $(41.94 \%)$. This is a rare activity for $48.39 \%$ of the respondents. Only $9.67 \%$ of the nurses report monthly research activities. According to existing studies, this production takes the form of master's thesis, doctoral dissertation, specialization and scientific initiation monographs, as well as books and presentations at scientific events. ${ }^{20}$

What the MSC nurses' professional practice is concerned, one may say that the primary function of this service is to offer support for patient care delivery in different situations. The predominant activity in this specific work is the management of different medical-hospital products' processing.

Nevertheless, the increasing supply of disposable medical-hospital material and the outsourcing of services have made several MSC activities obsolete. ${ }^{20}$ In addition, products have evolved and items originally manufactured for single use are being reused, incorporating new questions about the future of MSC work, which will certainly determine a new format for its structure and activities.

\section{CONCLUSIONS}

The study revealed the profile of nursing professionals working at MSC and permitted the evaluation of how frequently the activities these professionals are responsible for at this specialized service are accomplished. The MSC is characterized as a sector in health institutions whose work process comprises specific knowledge and practices, with distinctive objectives and goals when compared to other units. Due to its characteristics, its work is acknowledged as indirect care, equip- 
ping health care and offering the support needed for different care activities.

Among the 25 activities listed in the data collection instrument, which refer to validated activities that picture the work of nurses at MSCs, 15 activities are accomplished daily, nine monthly, 14 are not frequently accomplished and some never.

The research permitted the identification of research needs in the area of MSC, deepening nursing management knowledge and suggesting further research to assess the different facets of nurses and nursing teams' work.

\section{REFERENCES}

1. Silva A. Organização do trabalho na unidade centro de material. Rev Esc Enferm USP. 1998 Ago; 32(2):169-78

2. Moura MLA. Enfermagem em Centro de Material e Esterilização: apontamentos - saúde, 5. $2^{\mathrm{a}}$ ed. São Paulo (SP): SENAC; 1999.

3. Costa JA. Atividades de enfermagem no centro de material e esterilização: subsídios para o dimensionamento de pessoal [dissertação]. São Paulo (SP): Universidade de São Paulo; 2009.

4. Taube SAM, Zagonel IPS, Méier MJ. Um marco conceitual ao trabalho da enfermagem na Central de Material e Esterilização. Cogitare Enferm. 2005 Mai-Ago; 10(2):76-83.

5. Tonelli SR, Lacerda RA. Refletindo sobre o cuidar no centro de material e esterilização. Rev SOBECC. 2005; 10(1):28-31.

6. Machado RR, Gelbcke FL. Que brumas impedem a visibilização do centro de material e esterilização? Texto Contexto Enferm. 2009 Abr-Jun; 18(2):347-54.

7. Conselho Federal de Enfermagem (COFEN) [Internet]. Decreto n. 94.406/87. Regulamenta a Lei n. 7.498/86. 1987 [acesso 2012 Ago 27]. Disponível em: http:/ /www.portaleducacao.com. br/enfermagem/artigos/1735/decreto-n-94406-87regulamentacao-da-lei-n-7498-86

8. Agência Nacional de Vigilância Sanitária (ANVISA) [Internet]. Resolução - RDC n. 307, de 14 de novembro de 2002. Altera a Resolução - RDC n. 50 de 21 de fevereiro de 2002 que dispõe sobre o Regulamento Técnico para planejamento, programação, elaboração e avaliação de projetos físicos de estabelecimentos assistenciais de saúde. 2002 [acesso 2012 Ago 27]. Disponível em: http:// portal.anvisa.gov.br/wps/wcm/ connect/3f54b800474597439fb7df3fbc4c6735/ $\mathrm{RDC}+\mathrm{N} \% \mathrm{C} 2 \% \mathrm{BA}+307-2002$.pdf?MOD=AJPERES

9. BronzattiJAG. Otrabalho de enfermagem na unidade central de material: uma abordagem ergonômica [dissertação]. São Paulo (SP) Universidade de São Paulo; 2002.

10. Sociedade Brasileira de Enfermagem em Centro Cirúrgico. Recuperação anestésica e Centro de Material e Esterilização: práticas recomendadas. $4^{\mathrm{a}}$ ed. São Paulo (SP): SOBECC; 2007.

11. Agência Nacional de Vigilância Sanitária (ANVISA) [Internet]. Resolução RDC n. 15, de 15 de março de 2012. Dispõe sobre requisitos de boas práticas para o processamento de produtos para saúde e dá outras providências. 2012 [acesso 2012 Jul 5]. Disponível em: http://www.brasilsus.com.br/legislacoes/ gm/112548-15.html

12. Conselho Federal de Enfermagem (COFEN) [Internet]. Resolução COFEN n. - 424, de 19 de abril de 2012. Normatiza as atribuições dos profissionais de enfermagem em Centro de Material e Esterilização e em empresas processadoras de produtos para saúde. Diário Oficial da União, Brasília, DF (2012 Abr 23) [acesso 2012 Ago 27]. Disponível em: http:/ / site.portalcofen.gov.br/node/8990

13. Oliveira ADS, Santos AMR, Amorim FCM, Carvalho AMC, Câmara JT, Carvalho PMG. Aspectos sócio-políticos da implantação da central de transplantes de Piauí. Rev Bras Enferm. 2007 Jul-Ago; 60(4):405-9.

14. Google docs [Internet] [acesso 2011 Mai 4]. Disponível em: http://www.docs.google.com

15. Freitas H, Janissek-Muniz R, Andriotti FK, Freitas P, Costa RS. Pesquisa via Internet: características, processo e interface [Internet]. 2004 [acesso 2011 Jun 21]. Disponível em: http://www.ufrgs.br/gianti/ files/artigos/2004/2004_140_rev_eGIANTI.pdf

16. Malhotra N. Pesquisa de marketing: uma orientação aplicada. $4^{\text {a }}$ ed. Porto Alegre (RS): Bookman; 2006.

17. Taube SAM. O processo de trabalho da enfermeira na central de material e esterilização: uma perspectiva tecnológica aos instrumentos [dissertação]. Curitiba (PR): Universidade Federal do Paraná; 2006.

18. Costa Aguiar BG, Soares E, Costa da Silva A. Evolução das Centrais de Material e Esterilização: história, atualidades e perspectivas para a enfermagem. Enferm Global [online]. $2009 \mathrm{Fev}$ [acesso 2011 Jun 21]; (15). Disponível em http:/ / scielo.isciii.es/pdf/ eg/n15/pt_reflexion2.pdf

19. Taube SAM, Meier MJ. O processo de trabalho da enfermeira na Central de Material e Esterilização. Acta Paul Enferm. 2007 Ago; 20(4):470-5.

20. BartolomeiSRT, Lacerda RA. Trabalho do enfermeiro no Centro de Material e seu lugar no processo de cuidar pela enfermagem. Rev Esc Enferm USP. 2006 Set; 40(3):412-7.

21. Gil RB. O processo de notificação da queixa técnica de material de consumo de uso hospitalar no contexto do gerenciamento de recursos materiais em um hospital universitário público 
[dissertação]. Ribeirão Preto (SP): Universidade de São Paulo; 2011.

22. Silva AC, Aguiar BGC. O enfermeiro na Central de Material e Esterilização: uma visão das unidades consumidoras. Rev Enferm UERJ. 2008 Jul-Set;
16(3):377-81.

23. Ventura PFEV. Participação do enfermeiro na gestão de recursos hospitalares. Belo Horizonte: Universidade Federal de Minas Gerais; 2011. 